\title{
SITUS NGURAWAN: SEJARAH DAN POTENSINYA SEBAGAI SUMBER BELAJAR SEJARAH LOKAL
}

\author{
Novi Triana Habsari*
}

\begin{abstract}
Abstrak
Madiun merupakan sebuah wilayah di Propinsi Jawa Timur yang berbatasan langsung dengan Ponorogo dan Ngawi. Keistimewaan yang dimiliki oleh Madiun ini salah satunya banyak terdapat peninggalan-peninggalan bersejarah. Diantaranya terdapat prasasti Mruwak, Prasasti Klagen Serut, Prasasti Sendang Kamal, Situs Candi Wonorejo dan Situs Gelang-Gelang atau yang lebih dikenal sebagai Situs Ngurawan.

Penelitian ini bertujuan untuk mengetahui sejarah dan potensi dari Situs Ngurawan sebagai sumber belajar sejarah lokal khusus nya untuk siswa SMP di Madiun. Hal tersebut dimaksudkan karena masih banyak masyarakat Madiun khususnya generasi muda yang kurang mengetahui sejarah lokal disekitarnya.

Berdasarkan hasil penelitian, Keberadaan Ngurawan dan Gelang Gelang secara jelas termuat dalam prasasti Mula Malurung bertarikh 1255M. Prasasti ini antara lain menyebut sanak kadang dan keturunan Seminingrat yang dinobatkan sebagai raja di Negara bagian Tumapel Singasari. Di antaranya menyebutkan Nararya Turukbali, putri sang prabu Seminingrat yang menjadi permaisuri Jayakatwang, ditetapkan sebagai ratu kerajaan Gelang Gelang di daerah Wurawan. Prasasti ini belum menulis Jayakatwang sebagai raja Gelang Gelang. Prasasti ini baru menulis Jayakatwang sebagai kemenakan sang prabu Seminingrat dan menantunya. Tentu ini karena Jayakatwang adalah putra mahkota raja Kediri Sastrajaya. Pada masa itu Kertanegara jadi raja Daha atau di timur sungai Brantas, sementara Sastrajaya jadi raja Kediri di barat sungai Brantas.

Baru pada tahun 1271M Sastrajaya digantikan putranya bernama Jayakatwang [Buku Girindra: Pararaja Tumapel-Majapahit]. Pada tahun ini Sri Kertanegara mengangkat Jayakatwang sebagai raja Kadiri menggantikan ayahnya Sastrajaya, sementara Turukbali tetap bersemayam di Gelang Gelang. Sampai kemudian pada tahun 1292M, Jayakatwang yang berkuasa atas Kediri dan Gelang Gelang berhasil menghancurkan pemerintahan Kertanegara di Singasari. Tapi setahun kemudian Jayakatwang dihancurkan raden Wijaya. Sejak saat itu perlahan keberadaan Gelang Gelang surut. Ketika Majapahit berdiri, bekas wilayah Gelang Gelang berganti nama sebagai keraton Pandansalas. Adanya situs Ngurawan di Madiun tersebut tentunya bisa dijadikan sumber belajar sejarah lokal. Dengan datang langsung ke lokasi situs tentunya para siswa lebih leluasa dalam mempelajari situs tersebut sekaligus akan mengetahui banyak hal tentang sejarah lokal yang terdapat di lingkungan sekitarnya.
\end{abstract}

Kata Kunci: Situs, Ngurawan, Sejarah Lokal.

\section{Pendahuluan}

Masa sejarah adalah masa dimana manusia telah mengenal adanya tulisan. Hal tersebut terbukti dengan adanya beberapa peninggalan sejarah yang berupa prasasti dan situs. Di daerah Madiun sendiri banyak terdapat peninggalan sejarah masa lampu yang tersebar dibeberapa wilayah, diantaranya prasasti Klagen Serut, Prasasti Mruwak, Situs Candi Wonorejo dan juga Situs
Ngurawan. Salah satu dari peninggalan tersebut yaitu Situs Ngurawan, merupakan sebuah situs yang masih terus dikaji oleh beberapa ahli hingga saat ini. Berdasarkan penelitian para ahli, situs Ngurawan ini terletak di Desa Ngurawan, Dopolo Kabupaten Madiun Jawa Timur. Menurut Rosidin, tokoh masyarakat setempat, menambahkan di dusunnya memang tersimpan banyak peninggalan sejarah. Bahkan, dimungkinkan 
masih banyak situs penting lain yang masih terkubur rapat di dalam bumi. "Sejauh ini juga sudah banyak peneliti sejarah yang datang. Di dusun ini terdapat beberapa situs penting peninggalan zaman dahulu. Di antaranya Patung Parwati, yoni, bejana hingga sebuah kolam bekas petirtaan kuno. Persis di belakang Masjid Maqomul Hidayah juga terdapat makam Kyai Zainal yang merupakan sesepuh Dusun Ngrawan. "Situs-situs di sini tidak berdiri sendiri, memiliki keterkaitan dengan beberapa situs di daerah lain," terangnya.

Sejarah situs Ngurawan ini sangat menarik untuk dikaji lebih dalam lagi, hal itu dikarenakan situs Ngurawan ini masih terkait dengan Kerajaan Kadiri, Kerajaan Majapahit, Kerajaan Sogaten, dan juga terkait dengan sejarah berdirinya Kabupaten Madiun. Namun banyak diantara masyarakat khususnya para siswa yang kurang memahami sejarah yang ada di daerahnya. Kurangnya kesadaran masyarakat akan sejarah inilah juga yang menjadikan beberapa peninggalan tersebut kurang terawat bahkan banyak yang rusak dan hilang.

\section{METODE}

Dalam penelitian Situs Ngurawan (sejarah dan Potensinya Sebagai Sumber Belajar Sejarah Lokal), penulis menggunakan pendekatan kualitatif. Pendekatan tersebut merupakan metode penelitian yang digunakan untuk mendiskripsikan dan manganalisa fenomena, peristiwa, aktifitas sosial, sikap, kepercayaan, persepsi, pemikiran orang baik secara individual ataupun kelompok (Sukmadinata,2007:60. Dalam penelitian ini menggunakan pendekatan induktif dimana peneliti melakukan pengamatan terhadap situs Ngurawan dan beberapa SMP di Madiun, kemudian menarik kesimpulan secara umum dengan dukungan dari beberapa informasi, sehingga data yang diperoleh bersifat deskriptif. Jenis penelitian yang dilakukan yaitu penelitian deskriptif dalam catatan data in meliputi potret subjek, rekonstruksi dialog, deskripsi keadaan fisik, struktur tentang tempat, dan barang-barang lain yang ada disekitarnya. Demikian juga, catatan tentang berbagai peristiwa khusus (termasuk siapa yang terlibat dengan cara bagaimana, gerakgeriknya), dan juga tingkah laku atau sikap penelitiannya)(Sutopo). Pendekatan ini cocok untuk meneliti Situs Ngurawan (sejarah dan potensinya sebagai sumber belajar sejarah lokal). Penelitian ini dilaksanakan dngan menganalisis data yang diperoleh dari wawancara, dokumentasi, dan observasi langsung di lapangan. Selain itu sumber data pada penelitian ini diperoleh dari sumber primer yang diperoleh secara langsung dari sumber asli atau tidak melalui perantara (Silalahi,2003:57). Sumber ini bisa didapatkan langsung melalui wawancara dengan informan. Sumber lisan ini dapat diperoleh dengan mendeskripsi secara tertulis hasil dari pengamatan atau wawancara yang dilakukan. Informan pada penelitian ini yaitu tokoh masyarakat, komunitas pecinta sejarah Madiun, dan budayawan Madiun yang dianggap mengetahui sejarah Situs Ngurawan. Sedangkan data sekunder penulis peroleh dari buku-buku ataupun artikel referensi tentang situs Ngurawan seperti tulisan Siwi Sang (2014) yang berjudul "Situs Kerajaan Ngurawan Gelang-Gelang dan Pandansalas".

Dalam menganalisis data, peneliti menggunakan analisis kualitatif model interaktif (Sutopo,1999) sebagaimana bagan di bawah ini:

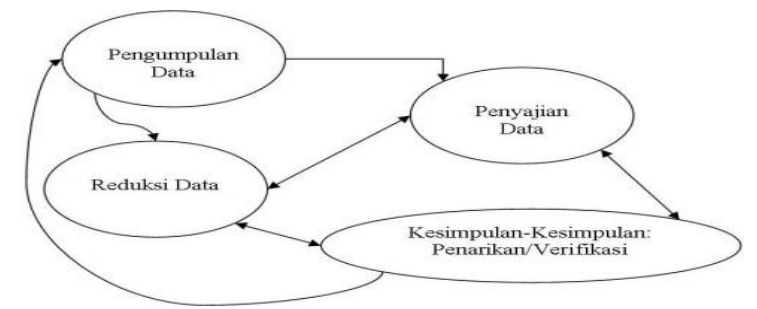

Bagan 1: Model Analisis Interaktif 


\section{Hasil Penelitian}

\section{Situs Ngurawan}

Situs Ngurawan ini terletak di Desa Ngurawan Kecamatan Dolopo Kabupaten Madiun. Dusun Ngrawan, Desa/Kecamatan Dolopo bakal disulap jadi objek wisata sejarah. Pemkab Madiun pun serius untuk menghidupkan kembali Kerajaan Ngurawan ini. Bahkan, dalam waktu dekat kawasan situs peninggalan bersejarah itu bakal dibangun sebuah gapura yang bernilai ratusan juta rupiah. Keberadaan Ngurawan dan Gelang-Gelang secara jelas termuat dalam Prasasti Mula Malurung bertarikh 1255 M. Prasasti ini antara lain menyebut sanak kadang dan keturunan Seminingrat yang dinobatkan sebagai raja di Negara bagian Tumapel Singasari. Diantaranya menyebutkan Nararaya Turukbali, putri sang prabu Seminingrat yang menjadi permaisuri Jayakatwang, ditetapkan sebagai ratu Kerajaan Gelang-Gelang di daerah Wurawan (Siwi Sang:2014).

Ketika Majapahit berdiri, bekas wilayah Gelang-Gelang berganti nama menjadi Keraton Pandansalas. Nama Keraton Pandansalas juga diketemukan dalam berita Pararaton. Begitu pula pada buku Girindra Pararaja Tumapel, Majapahit yang juga menuliskan bahwa terdapat tiga Raja yang memerintah di Pandansalas pada jaman Kerajaan Majapahit, diantaranya:

1. Ranamenggala dyah Sumirat dengan gelar Bhre Pandansalas yang memerintah antara tahun 1375M$1400 \mathrm{M}$

2. Raden Jagulu dengan gelar Bhre Pandansalas II yang memerintah antara tahun 1400M-1430M.

3. Singawikrama Wardhana dyah Suraprabhawa denga gelar Bhre Pandansalas III yang memerintah antara tahun $1430 \mathrm{M}-1447 \mathrm{M}$.
Bhre pandansalas III sejak tahun 1447M menjadi raja di Keraton Tumapel dan antara tahun 1466M-1478M menjadi maharaja Majapahit. Berdasarkan penafsiran Serat pararaton bait terakhir, Sri Singawikrama Wardhana dyah Suraprabhawa wafat di kedaton Majapahit pada tahun 1478M akibat gempuran 4 putra Sang Sinagara yang masih termasuk keponakannya untuk merebut singgasananya.

\section{Perkembangan Situs Ngurawan}

Adanya penemuan-penemuan terkait dengan keberadaan kerajaan Ngurawan di Desa Ngurawan, Dolopo, Kabupaten Madiun ini membuat Pemerintah Kabupaten Madiun berfikir untuk menjadikan Desa Ngurawan ini sebagai tempat tujuan pariwisata. Hal tersebut nampaknya dibuktikan dengan mulai dibangunnya gapura masuk ke situs Ngurawan. Tidak hanya itu, namun Pemerintah Kabupaten juga menggelontorkan dana untuk memperbaiki sarana dan prasarana yang ada di sekitar situs. (wawancara dengan mbah Wo.2015).

Pernyataan tersebut dipertegas oleh terang Kabid Pariwisata Dinkoperindagpar Kabupaten Madiun yaitu Isbani, yang mengatakan bahwa Pembangunan fisik yang digawangi Dinas Koperasi Perindustrian Perdagangan dan Pariwisata (Dinkoperindagpar) Kabupaten Madiun telah dirancang sedemikian rupa. Tidak asal jadi, tapi disesuaikan dengan tema kawasan tersebut. Triwulan pertama (Januari-Maret) kami matangkan perencanaannya. Model gapura harus dirembug bersama pakar sejarah dan warga setempat. Gambaran awal, gapura yang dibangun persis di pintu masuk jalan dusun atau di pinggir Jalan Raya MadiunPonorogo itu bernuansa kuno. Era pra- 
Majapahit sebagaimana keberadaan Kerajaan Ngurawan tersebut. "Bisa jadi nanti dibangun dengan menggunakan struktur batu bata ekspos yang kental nuansa klasik," terangnya.

Setelah konsep matang, pembangunan fisik gapura akan direalisasi pada triwulan kedua (April-Juni) nanti. Diharapkan proses pengerjaannya tak sampai melampaui triwulan kedua tersebut. "Setelah ada gapura, keberadaan situs sejarah di Dusun Ngrawan diharapkan bisa lebih aman. Juga masyarakat yang hendak berkunjung bisa melihat tanda masuk dengan lebih jelas dan tak bingung lagi," imbuhnya.

Untuk pembangunan gapura, Dinkoperindagpar Kabupaten Madiun telah menyiapkan dana Rp 199,5 juta. Dana dari APBD 2016 itu sengaja dialokasikan untuk merealisasikan Dusun Ngrawan sebagai salah satu destinasi wisata sejarah di Kabupaten Madiun. Menurut Isbani, Potensi pariwisata sejarah Kerajaan Ngurawan sejauh ini belum tergali maksimal. Namun, pelan tapi pasti semua akan ditata dan siapkan menjadi desa wisata baru.

Keberadaan situs Ngurawan ini semakin terkenal setelah diadakannya Festival Gelang-Gelang oleh Komunitas Pecinta Sejarah Madiun Raya (Kompas Madya) yang digawangi oleh Bernadi. Festival tersebut bertujuan untuk memperkenalkan adanya Situs Ngurawan pada khalayak. Festival itu diikuti oleh sejarawan dan pecinta seni dari berbagai daerah dan dilaksanakan selama satu minggu dengan beberapa agenda yang menarik, diantaranya pawai budaya yang diikuti oleh masyarakat sekitar serta gabungan dari beberapa budayawan dengan menampilkan kesenian ciri khas dari masing-masing daerahnya. Diantara para sejarawan dan budayawan yang terlibat, terdapat pula beberapa turis asing yang tertarik untuk menyaksikan dan ikut serta dalam Festival Gelang-Gelang tersebut.

Penemuan situs Ngurawan tersebut menarik perhatian Balai Arkeologi Jogjakarta. Mereka terus melakukan penelitian dan juga eskavasi (penggalian) lebih mendalam untuk memperjelas situs tersebut peninggalan dari kerajaan apa dan berapa usianya. Selama penelitian, Tim Balai Arkeologi Jogyakarta telah menyelesaikan 10 hari eskavasi di Situs Ngurawan Desa Dolopo Kecamatan Dolopo. Kesimpulan sementara, tim menemukan sebuah pemukiman masyarakat kuno yang hidup 600 tahun lalu. Setelah 10 hari melakukan penggalian dan penelitian, tim Balai Arkeologi Jogyakarta, menyimpulkan jika lokasi ditemukannya berbagai macam benda bersejarah, adalah sebuah pemukiman masyarakat kuno.

Kesimpulan itu didapat setelah ditemukannya tumpukan batu bata besar, yang tertata rapi seperti layaknya tembok di areal pekarangan rumah Gatot, warga Dukuh Ngurawan, Desa Dolopo, Kecamatan Dolopo. Tidak hanya 1 lokasi, tumpukan batu bata tersebut, juga ditemukan di 5 lokasi berbeda.

Staf Balai Arkeologi Jogjakarta, Rita Istari mengungkapkan, sebelumnya tim juga menemukan berbagai macam pecahan perabot rumah tangga dari tanah liat, patung, serta batu yang menyerupai lumpang, dan uang kuno.

Selain itu, tim arkeologi juga menemukan beberapa benda yang diduga kedaton Kerajaan Ngurawan, jaman Kerajaan Majapahit pada abad 13-15 Masehi. Penggalian ini telah mendapat respon positif dari pemerintah Kabupaten Madiun agar situs Ngurawan nantinya bisa menjadi objek wisata budaya. (Stenpo.2015) 
Adanya penemuan demi penemuan dari Balai Arkeologi Jogjakarta setidaknya sedikit menguak misteri yang tersimpan pada situs Ngurawan. Hal tersebut tentunya juga berdampak pada mulai munculnya kesadaran warga sekitar situs untuk menjaga dan merawat peninggalanpeninggalan sejarah masa lampau yang ada di desanya. Menurut Syaifudin, Kepala Dusun setempat. Selama ini masyarakat hanya hanya membiarkan benda-benda bersejarah yang telah diketemukan, seperti misalnya umpak batu yang ditemukan di pekarangan rumah Slamet justru digunakan sebagai penyangga jembatan selokan di depan rumahnya. Begitu juga lingga yoni yang hanya dibiarkan begitu saja di pekarangan.

Rosidin, tokoh masyarakat setempat, menambahkan di dusunnya memang tersimpan banyak peninggalan sejarah. Bahkan, dimungkinkan masih banyak situs penting lain yang masih terkubur rapat di dalam bumi. Rosidin menegaskan sejauh ini juga sudah banyak peneliti sejarah yang datang. Baru-baru ini bahkan juga ada peneliti dari Brunei Darussalam yang datang. Masih menurut Rosidin, di dusun ini terdapat beberapa situs penting peninggalan zaman dahulu. Di antaranya Patung Parwati, yoni, bejana hingga sebuah kolam bekas petirtaan kuno. Persis di belakang Masjid Maqomul Hidayah juga terdapat makam Kyai Zainal yang merupakan sesepuh Dusun Ngrawan. Masih banyak teka-teki yang belum terungkap secara gamblang di Ngurawan. Karena itu, upaya penelitian dan diskusi perlu digalakkan lebih intens. Peran serta dan juga perhatian pemerintah dalam pemeliharaan cagar budaya sangat diperlukan. Tidak sebatas pendekatan fisik tetapi juga memberikan dukungan moril untuk pelestarian kawasan sejarah ini. Setidaknya, setahun sekali ada even budaya untuk pelestarian kawasan Ngrawan ini seperti festival Glang-Glang yang telah dilakukan.

\section{Potensi Situs Ngurawan sebagai Sumber Belajar Sejarah}

Sebagai salah satu peninggalan sejarah, tentunya keberadaan Situs Ngurawan ini memiliki arti penting bagi Pemerintah kabupaten Madiun dan juga masyarakat Madiun sendiri. Hal ini dapat diketahui dari sikap Pemerintah Kabupaten Madiun dan juga masyarakat sekitar situs. Situs Ngurawan ini membuktikan bahwa Madiun dahulunya merupakan wilayah yang diperhitungkan pada masa kerajaan Majapahit. Dari Ngurawan pula kita mengetahui bahwa Pemerintahan pertama di Kabupaten Madiun berasal. Begitu berartinya situs Ngurawan ini sehingga layak untuk dijadikan sebagai sumber belajar sejarah. Namun, untuk membuktikannya kita harus terlebih dahulu mengetahui sikap pemerintah dan masyarakat terhadap situs tersebut.

Peran pemerintah Kabupaten Madiun serta masyarakat sangat dibutuhkan dalam upaya melestarikan dan manjaga Situs Ngurawan. Untuk itu perlu adanya keberlanjutan program-program dari pemerintah untuk lebih meningkatkan kesadaran masyarakat akan pentingnya sejarah Nasional. Terlebih lagi selain sebagai salah satu cagar budaya, Situs Ngurawan ini juga berpotensi untuk dijadikan sebagai sumber pembelajaran sejarah bagi para pelajar. Hal itu sekaligus dapat meningkatkan kecintaan para pelajar khususnya di Madiun terhadap sejarah bangsanya sendiri.

Jika dilihat dari benda-benda peninggalan sejarah yang diketemukan seperti patung dewi Sri, lingga yoni, dan batu bata masa Majapahit, maka dapat 
dikaitkan dengan sumber pembelajaran sejarah pada masa kerajaan Hindu. Berdasarkan KTSP, peninggalan Hindu merupakan materi pembelajaran IPS kelas VII semester 2, yaitu terdapat dalam Standar Kompetensi 5. Memahami perkembangan masyarakat sejak masa Hindu-Budha samapai sekarang. Tepatnya Kompetensi dasar 5.1. Mendeskripsikan perkembangan masyarakat, kebudayaan, dan pemerintahan pada masa HinduBudha, serta peninggalan-peninggalannya. Oleh karena itu Situs Ngurawan sangat berpotensi sebagai sumber belajar IPSSejarah terutama bagi satuan pendidikan SMP kelas VII semester 2 .

Berbicara mengenai pelajaran sejarah, banyak siswa mengeluhkan bahwa pelajaran sejarah adalah pelajaran yang membosankan. Sejarah hanya menghafalkan angka tahun, bahkan tidak jarang guru hanya membacakan kembali materi yang sudah terdapat pada buku ajar. Berdasarkan fakta yang ada, masih banyak guru sejarah yang latar belakang pendidikannya bukan dari jurusan sejarah sehingga dimungkinkan pengetauan yang disampaikan kepada siswa tidak tepat sasaran. Terlebih lagi cara menyampaikan materi dalam pembelajaran sejarah masih monoton dengan tidak menggunakan metode maupun media yang menarik. Berangkat dari hal tersebutlah kami berusaha mengajak kepada guru dan siswa untuk mengadakan pembelajaran di luar kelas. Karena dengan belajar di luar kelas siswa akan lebih leluasa dalam berekspresi, refresh, dan diharapkan akan lebih termotivasi untuk mempelajari sejarah.

Sumber belajar adalah sarana pembelajaran dan pengajaran yng sangat penting. Sudah menjadi keharusan bagi seorang guru untuk mengeksplorasi berbagai macam sumber belajar untuk mendapatkan alat bantu yang tepat untuk mengajar dan melengkapi apa yang sudah disediakan dalam buku cetak, untuk menambah informasi, untuk memperluas konsep, dan untuk membangkitkan minat peserta didik. (Kochhar,2008:160). Sehingga dengan mereka terjun langsung untuk belajar, maka peserta didik akan mendapat pengetahuan baru tentang peninggalan kebudayaan nenek moyangnya. Keberadaan situs Ngurawan ini tentunya sangat bermanfaat dalam memberikan pengetahuan baru kepada peserta didik. Selain itu dengan mengunjungi situs ngurawan, maka diharapkan dapat meningkatkan kesadaran terhadap pelestarian budaya di sekitar tempat tinggalnya.

\section{Penutup}

Keberadaan situs Ngurawan di Dolopo Kabupaten Madiun sangat bermanfaat bagi perkembangan pengetahuan peserta didik mengenai sejarah lokal yang merupakan cikal bakal dari berdirinya Madiun. Dengan mengajak peserta didik untuk langsung mengunjungi situs Ngurawan tersebut, maka peserta didik akan mendapatkan pengalaman belajar langsung dengan suasana yang santai dan fresh. Selama ini pembelajaran yang hanya terpaku dalam suasana kelas yang kaku akan membuat pengetahuan siswa terisolasi. Mereka hanya mampu berimajinasi dari halhal yang disampaikan oleh guru. Misalnya ketika guru menjelaskan mengenai peninggalan Hindu, yaitu candi Prambanan. Maka siswa yang belum pernah kesana hanya akan mengandalkan imajinasinya untuk menggambarkan bagaimana bentuk candi prambanan yang megah. Namun apabila siswa langsung diajak menuju sebuah situs atau objek pembelajaran, maka peserta didik akan mempu lebih mengeksplorasi apa yang dia lihat dan amati. Selain itu peserta didik akan lebih menghargai dan melestarikan 
peninggalan kebudayaan dari nenek moyangnya. Untuk itu perlu kiranya kita sebagai pendidik menerapkan pembelajaran di luar kelas. Salah satu nya dengan menjadikan situs Ngurawan sebagai sumber belajar sejarah lokal pada siswa SMP.

\section{Daftar Pustaka}

Kochhar.2008. Pembelajaran Sejarah. Jakarta: PT. Gramedia

Silalahi. 2003. Metodologi Penelitian Sosial. Jakarta: Revika Adituma

Siwisang. 2014. Situs Kerajaan Ngurawan Gelang-Gelang dan Pandansalas
Sukmadinata Nana. 2007. Metode Penelitian Pendiikan. Bandung: PT. Remaja Rosdakarya

Sutopo.H.B.2002. Metode Penelitian Kualitatif. Surakarta: Sebelas Maret University Press

Http://www.Antaranews.com. Arkeolog Gali Situs Ngurawan Madiun. 16 September 2016. Diakses pada 25 September 2016

Http://www.Antaranews.com. Melihat Siswasisa Kejayaan Majapahit di Situs Ngurawan Madiun. 24 September 2016. Diakses pada tanggal 25 September 2016 Http://www.Stenpo. Hasil Penggalian Situs Ngurawan. 2 Oktober 2016. Diakses pada tanggal 26 September 2016 